\title{
Single-Parent Family as a Factor of Using Psychoactive Substances by Senior Pupils
}

\section{Неповна сім'я як чинник вживання старшокласниками психоактивних речовин}

\author{
Iryna Kompliienko \\ Leading Law Expert of State Institution «Center for Mental \\ Health and Monitoring of Drugs and Alcohol of Ministry of Health \\ of Ukraine», Kyiv (Ukraine) \\ ORCID ID: https://orcid.org/0000-0001-5007-8779 \\ Researcher ID: AAL-4652-2020 \\ e-mail: komplienko78@ukr.net
}

\section{Ірина Комплієнко}

Провідний судовий експерт Державної установи «Центр психічного здоров'я і моніторингу наркотиків та алкоголю Міністерства охорони здоров'я України», м. Киӥв (Україна)

\section{ABSTRACT}

The purpose of this article is to outline the negative side of a single-parent family's affect on parents-children relationships; to describe the psychological types of parents-children relationships; to highlight the psychological factors of maladaptive relationships between one parent and senior pupil in a sigle-parent family.

Methods of the research. The following theoretical methods of the research were used to solve the tasks formulated in the article: a categorical method, structural and functional methods, the methods of the analysis, systematization, modeling, generalization. Method of interviewing was used as empirical one.

Address for correspondence, e-mail: kpnu_lab_ps@ukr.net Copyright: (C) Kompliienko Iryna

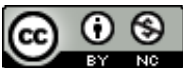

The article is licensed under CC BY-NC 4.0 International (https://creativecommons.org/licenses/by-nc/4.0/)

(C) Kompliienko Iryna

DOI (article): https://doi.org/10.32626/2227-6246.2020-49.177-201 
The results of the research. It is noted that a single-parent family is often the result of a change of the child's attitude towards his / her mother. Sometimes he / she has a rather heightened sense of pity and tenderness for his / her mother; in other cases, the child accuses the mother in caring for his / her father, especially if the child sees and appreciates such qualities of father's character that the mother does not notice. On the contrary, the child cannot notice those aspects of parental character that have become a source of frustration for his / her mother. As a result, the child begins to be quite critical to his / her mother and, thus, gradually "loses" to himself / herself the other parent (who lives in another family). Such increasing in the distance between a child and a parent takes place even when the mother, depressed by her grief and new additional worries, does not find enough time to practice with her child. It is often in such cases the child is regarded by the abandoned mother as the unnecessary burden, which significantly complicates her further life perspectives. As a result, there is a rather crude, sometimes - completely unjust attitude of the mother to her child, which, in turn, is extremely detrimental to the child's moral development, however, as a frantic maternal love, or love-victim, which often takes a special place in such situations and it doesn't have reasonable boundaries.

It is proved that in a new family it isn't also quite common for children to adapt to new living conditions. A senior pupil has a psyche that is still incompletely formed and easily destroyed. As a rule, it is not easy for the child to get used to a stepfather or a stepmother, and this process of psychological adaptation sometimes takes a long and painful character. A suspicious, alert, and sometimes even hostile attitude towards a new father or a mother quite often disappears over a long period of time, even if one parent is paying the special attention to the child. In many cases, family relationships remain destructive.

Conclusions. The psychological factors of maladaptive relationships of one parent and a senior pupil in the single-parent family were identified: unhealthy, conflict situation in the family; the situation of divorce, which significantly exacerbates all negative characteristics of the spouse, actualizes the atmosphere of mutual hostility, hatred, abuse and mutual accusations, which in a great degree affect the child's worldview, his / her ethical and moral beliefs, attitudes, wishes; poor mental and (or) physical condition of a wife-mother; negative family experience of a mother; negative conditions for co-existence (or the existence of slight degree) of the influence of the man in the family (including the male authority); the use of psychoactive substances by senior pupils.

(c) Kompliienko Iryna

DOI (article): https://doi.org/10.32626/2227-6246.2020-49.177-201 
Key words: single-parent family, complete family, psychoactive substances, maladaptive relationships, conflict situation, divorce situation, negative family experience.

\section{Вступ}

Сім'ю, у якій немає одного з батьків, прийнято називати неповною. У зарубіжних дослідженнях давно існує та широко використовується термін «материнська сім'я», який говорить сам за себе, але, водночас, у дослідженнях визнається соціальна і психологічна рівноправність батьків. Сам по собі термін «неповна» означає «недосконала», «сформована поза нормою», тобто все-таки збиткова, якій чогось або когось не вистачає до досконалості або хоча б до норми. Норма ж у суспільній свідомості есплікується в парадигмі необхідного трикутника батько - мати - дитя (Максименко, Ткач, Литвинчук \& Онуфрієва, 2019; Стегачёва, 2004).

Найчастіше сім'я залишається без батька. Нами було проведено соціологічне дослідження впродовж 2015-2016 pp. на репрезентативній вибірці старшокласників із 6000 осіб. Ми ставили школярам запитання: «Чи у Вашій сім’ї є батько та мати, чи Ваші батьки розлучені або не живуть разом?» Із усіх опитаних старшокласників $47 \%$ відповіли, що їх сім'я є неповною. Знову ж таки, з решти 53\% школярів 45,5\% наголосили, що у їх батьків (обох або одного з них) це - вже друга або третя чи більше сім'я. I лише 7,5\% старшокласників стверджували, що у їх батьків це - перший шлюб. Із усіх неповних сімей у $18 \%$ діти живуть із батьком й у $82 \%$ - із матір'ю.

Однак, не тільки дитина чоловічої статі, яка виховується без батька, може зазнавати труднощів у психічному розвитку через несформованість чоловічих рис характеру. В плані формування "образу чоловіка» досвід взаємостосунків із батьком є досить-таки важливим i для дівчаток. «Коли такого досвіду не існує або він - несуттєвий, - зауважує М. І. Буянов, «образ чоловіка» виявляється дещо збідненим,

(C) Kompliienko Iryna

DOI (article): https://doi.org/10.32626/2227-6246.2020-49.177-201 
що згодом призводить до збіднення і спрощеності в особистісних взаємостосунках" (Буянов, 1988: 73). На цьому також наголошує й Ф. Дальто, підкреслюючи, що спілкування з батьком готує дівчинку до «виходу» у великий світ, який наполовину складається із суб’єктів чоловічої статі, що великою мірою позначається на її вибірковому ставленні до них. Так, заміжне життя жінки багато в чому визначатиметься тими взаємостосунками, які склалися у неї з батьком ще в дитинстві (Дальто, 1997).

Нерідко наслідком розпаду сім'ї є зміна ставлення дитини до своєї матері. Іноді у неї виникає досить-таки загострене почуття жалості й ніжності до неї; в інших випадках дитина звинувачує матір у розірванні стосунків із батьком, тим більше, якщо в ньому дитина бачить і цінує такі якості та властивості характеру, які не помічає мати. Або, навпаки, дитина може не помічати ті сторони батьківського характеру, які стали джерелом розчарування для їі матері. Унаслідок цього дитина починає досить-таки критично ставитися до матері й, отже, за своєю суттю ніби «втрачає» для себе і другого з батьків. Збільшення відстані між дитиною та батьками має місце й тоді, коли мати, пригнічена своїм горем i новими додатковими турботами, не знаходить достатньо часу для занять із дитиною. Нерідко буває й так, що дитина в таких випадках розглядається покинутою мамою як зайвий тягар, що суттєво ускладнює її подальші життєві перспективи. У підсумку виникає досить-таки грубе, часом - зовсім несправедливе ставлення матері до дитини, що, своєю чергою, вкрай згубно позначається на їі моральному розвитку, втім, як і несамовита материнська любов, або любов-жертва, що нерідко виникає в такій ситуації та не знає розумних меж.

Отже, мета цієї статті - окреслити негативний вплив розпаду сім'ї на взаємостосунки батьків і дітей; описати психологічні типи взаємостосунків батьків і дітей; виокремити психологічні чинники дезадаптивних взаємостосунків одного з батьків і старшокласника в неповній сім'̈і.

(c) Kompliienko Iryna

DOI (article): https://doi.org/10.32626/2227-6246.2020-49.177-201 


\section{Методи дослідження}

Для розв'язання поставлених у роботі завдань використано такі теоретичні методи дослідження: категоріальний, структурно-функціональний, аналіз, систематизація, моделювання, узагальнення. У якості емпіричних методів обрано методи анкетування й інтерв'ювання.

\section{Результати та дискусії}

Існуючі в психологічній літературі емпіричні дані дають підстави говорити про те, що й повторний шлюб, укладений після розлучення батьків, як правило, не здатний компенсувати дитині той збиток, який був нанесений їй вихованням у неповній сім’ї (Гарбузов, 1990).

У новоствореній сім'ї також нерідко виникають неабиякі труднощі адаптації дітей до нових умов життєдіяльності. Дитина у старшому шкільному віці вирізняється психікою, яка є ще не цілковито сформована, якій легко завдати шкоду. Дитині, як правило, нелегко звикнути до вітчима або мачухи, і сам цей процес психологічної адаптації часом набуває тривалого і болісного характеру. Досить часто підозріле, насторожене, іноді - й узагалі вороже ставлення до нового батька чи матері зникає упродовж тривалого періоду часу, навіть якщо один із батьків виявляє максимальну увагу до дитини. У багатьох же випадках сімейні взаємостосунки залишаються деструктивними.

У психологічній літературі існують емпіричні дані, що у новоствореній сім'ї в дитини нерідко погіршуються взаємостосунки також і з рідною для неї матір'ю або батьком. Порівняння деяких важливих соціально-психологічних характеристик дітей, які живуть у сім'ях, де мати після розлучення вийшла заміж удруге, і в сім'ях, де дитина жила тільки з матір'ю, відповідно до деяких зарубіжних досліджень, свідчить про те, що взаємостосунки мати - дитина є набагато кращими в сім'ях, де дитина виховується лише

(C) Kompliienko Iryna DOI (article): https://doi.org/10.32626/2227-6246.2020-49.177-201 
матір'ю. Вивчення ступеня експлікації таких особистісних якостей дітей, як замкненість, збудженість, неврівноваженість, агресивність, озлобленість тощо, свідчить про те, що ці якості найбільшою мірою властиві дітям у сім'ях із нерідною матір'ю або батьком (Раттер, 1978).

Отже, розлучення з урахуванням попередніх і наступних психологічних характеристик можна вважати цілісним комплексом несприятливих чинників, здатних здійснювати негативний вплив на психічне і моральне становлення дітей, що, своєю чергою, може призвести до вживання дітьми психоактивних речовин, скоєння ними криміногенних правопорушень або навіть до психосоматичних розладів (Пожар, 1996). Для з'ясування кількості таких негативних психологічних чинників у сучасному суспільстві та з метою ïх порівняння з минулим століттям нами було проведено пілотне дослідження, у якому брали участь 254 психологи середніх освітніх закладів м. Києва, м. Рівного та м. Миколаєва (дослідження проводилося у 2017 р.). Так, психологи стверджують, що розлучення батьків у $25 \%$ випадків призводить до скоєння дитиною криміногенних правопорушень (80-90\% таких вчинків здійснено під впливом неформальної, значущої для старшокласників групи). Своєю чергою, 35-38\% старшокласників починають вживати психоактивні речовини, і лише у 8\% таких дітей діагностуються психосоматичні розлади. Якщо порівняти ці дані з результатами соціологічних опитувань, проведених у 70-80-х рр. минулого століття, то неповна сім'я була причиною скоєння дитиною злочинів у середньому в $42 \%$ респондентів, починали вживати психоактивні речовини $23-25 \%$ дітей, психосоматичні розлади діагностувалися у 13-15\% респондентів (Tabachnikov, Kharchenko \& Prib, 2011: 61-66). Отже, як бачимо, в сучасних умовах відсоток старшокласників, які починають вживати психоактивні речовини внаслідок розлучення їх батьків, є значно вищим. Тому, перш ніж зважитися на розлучення, батьки мають урахувати всі можливі (C) Kompliienko Iryna

DOI (article): https://doi.org/10.32626/2227-6246.2020-49.177-201 
негативні наслідки, що можуть позначитися на здоров'ї, поведінці та загалом - на майбутньому дитини.

Багато науковців і вчених на підставі проведених емпіричних досліджень показали, що у шлюбі в респондентів діагностуються неусвідомлені тенденції щодо повторення моделі сім'ї своїх батьків, і це може суттєво негативно впливати на майбутню сім'ю. Існують емпіричні дані, які свідчать про те, що дитина, яка виховується в неповній сім’ї, має меншою мірою виражений або ж негативний досвід підготовки до сімейного життя, тому ймовірність розпаду шлюбу у вихованців неповних сімей є значно вищою порівняно 3 тими, хто виховується у повних сім'ях. Перші діти частіше залишаються неодруженими і бездітними (OECD Health Data 2008: How Does Canada Compare (PDF), 2008).

Отже, наявність батька і матері в сім’ї становить надзвичайно важливу психологічну передумову адекватного емоційно-морального розвитку дитини в сім’ї. Важливість і актуальність цієї передумови зробили їі предметом досліджень E. V. Kioseva, у працях якої висловлювалася одностайна думка, що найбільшою мірою проблематичною i вразливою в психологічному плані є неповна сім'я (Kioseva, 2015: 61-62). Сучасні вітчизняні та зарубіжні автори нерідко говорять щодо обмежених виховних можливостей неповної сім’ї. У неповній сім’ї частіше, ніж у два рази, діти скоюють правопорушення у неповнолітньому віці. Це відбувається внаслідок того, що атмосфера неповної сім’ї актуалізуе вищі шанси ризику долучення дітей до спиртних напоїв і зловживання ними (Osukhovskaia, 2011).

Більшою мірою, ніж у повній родині, в неповній сім’і виявляються педагогічно занедбані діти. Відповідно до думки А. Я. Луп’ян, структура сім’ї суттєво впливає на формування ціннісних орієнтацій і трудових настановлень дітей, які потім також виявляються у дорослої людини (Лупьян, 1986). У дослідженнях науковців доведено, що робітники, які виховувалися в повних сім'ях, висувають вищі вимоги (C) Kompliienko Iryna DOI (article): https://doi.org/10.32626/2227-6246.2020-49.177-201 
до змісту праці, до їі творчого характеру. Вони беруть більш активну участь у громадській роботі, організації праці, діяльності соціуму. В робітників, які, своєю чергою, виховувалися в неповних сім'ях, домінуючою залишається орієнтація на працю як на можливість стати незалежною, самостійною особистістю (Balakireva, Bondar \& Pryimak, 2015).

Отже, розпад сім’ї негативно впливає на взаємостосунки батьків і дітей. Їх можна розділити на два психологічні типи. Перший тип базується на тому твердженні, що в зв'язку з розлученням порушується емоційна рівновага матері. Їй не вистачає емоційних сил, щоб допомогти дитині у важкий для неї період. Ця ситуація суттєво ускладнюється тим, що, втративши емоційний, довірчий зв'язок із дитиною в старшому шкільному віці, для матері залишається небезпека не відновити її ще довгі роки. А оскільки за законодавством багатьох країн після розлучень діти залишаються з матерями, то особливі наслідки, як правило, мають ситуації, коли син залишається з матір'ю.

Другий тип взаємостосунків пов'язаний зі ставленням матері до сина. Такий тип детально описується в дослідженнях Е. Еріксона. Як приклад учений наводить кілька пацієнтів із патогенетичними тенденціями. Цих незнайомих між собою людей об’єднувало одне - характери їх матерів, а саме те, що вони дуже сильно і відчайдушно любили своїх дітей. Водночас ці матері звикли до постійного схвалення і визнання зі сторони оточуючих, що, зазначає Е. Еріксон, негативно впливає на їх дітей. Подібних матусь із гіперопікою вирізняє від «звичайних» невлаштованість своєї суто жіночої долі. Часто вони занадто домінують над своїми чоловіками, прагнуть у будь-якому випадку, в будь-якій ситуації показати свою владу. Ця невлаштованість, невезіння з чоловіками прямо протилежним чином проектується на синів (Эриксон, 1996).

Один пацієнт, який був єдиною дитиною в сім'ї, одного разу на прийомі в Е. Еріксона висловився так: «Мати наста(C) Kompliienko Iryna

DOI (article): https://doi.org/10.32626/2227-6246.2020-49.177-201 
вила мені «шишки» своєю надмірною любов’ю, від чого у мене залишилися синці на все життя» (Эриксон, 2000: 58). Необхідність вчасно ніби «відірвати» від себе синів є для всіх матерів особливим завданням, і при цьому вони не мають очікувати або навіть вимагати за це подяки. Внутрішнє самовідчуття дитини в цьому випадку є настільки складним, що вона може відчувати ненависть щодо матері або нею опановує неабияке бажання позбутися їі влади. Побоювання, що ці почуття можуть проявитися, викликає у дитини почуття провини, що також може бути причиною вживання нею психоактивних речовин.

Матусі ревниво ставляться до своїх синів, віддають їм усю ту любов і ніжність, яку не розтратили в своєму житті 3 чоловіками. У результаті в синів утворюється нерозривний зв'язок зі своїми матерями, який навіть із роками важко зруйнувати. Образ батька протилежної статі, як правило, суттєво впливає на вибір партнера в майбутньому.

Хлопчики, незважаючи на те, у якій сім'ї вони виховуються, завжди прагнуть до незалежності; вони стверджують свою індивідуальність, намагаючись відокремитися безпосередньо від вихователя, зазвичай - від матері. Для дівчаток більш прийнятною є взаємозалежність: вони, таким чином, знаходять власну індивідуальність у своїх соціальних зв'язках.

Перераховані об'єктивні показники негативного впливу виховного потенціалу неповної сім’ї можуть бути доповнені показами самих матерів-одиначок. Вони частіше, ніж жінки з повних сімей, стурбовані поганим навчанням сина або дочки (на це вказали 72,3\% матерів із неповної сім’ї та $46,4 \%$ - з повної), грубістю дитини у спілкуванні та взаємостосунках (відповідно 77,1\% і 45,3\%), поганою поведінкою в школі $(65,4 \%$ і $24,1 \%)$, неприйнятною дружбою з поганими товаришами $(68,2 \%$ і $20,6 \%)$, занадто раннім проявом інтересу до однолітка протилежної статі $(65,7 \%$ і 38,4\%). ЗЖінки з неповних сімей, як правило, пояснюють такі проб-

(C) Kompliienko Iryna DOI (article): https://doi.org/10.32626/2227-6246.2020-49.177-201 
леми тим, що вся турбота щодо виховання дитини в неповній сім'ї повною мірою лягає на плечі жінки, - це, перш за все, турбота щодо створення необхідних матеріально-побутових умов свого життя. При цьому наголошено, що в разі розпаду шлюбного зв'язку збереження і навіть підвищення колишнього життєвого рівня дитина, як правило, розглядає як питання зростання ролі престижу для жінки, тому вона береться за важчу роботу, знаходячи додатковий заробіток.

Постійна зайнятість жінки-матері у професійній сфері, турботи щодо ведення домашнього господарства та пов'язані 3 цим нервова напруженість, утома тощо негативно позначаються на ставленні до дитини (неврівноваженість, дратівливість тощо). Усе це, врешті-решт, обертається неповними можливостями сімейного виховання, дефіцитом спілкування, призводячи до нестачі уваги щодо дитини, їі справжніх інтересів і потреб, послаблення контролю за її поведінкою.

Більш того, діти в неповних сім'ях удвічі частіше, ніж у повних, узагалі залишаються без будь-якого нагляду, адже матеріальні й тимчасові проблеми життєдіяльності обертаються проблемами бездоглядності дітей, що також нерідко призводить до вживання дітьми психоактивних речовин. Крім того, дефіцит матеріальних і тимчасових можливостей неповної сім'ї так чи інакше обмежує участь жінки-матері в культурному, освітньому, громадському житті й, тим самим, не тільки суттєво збіднює духовне життя сім'ї, але й призводить до повної втрати авторитету батька.

Як свідчать результати проведеного нами пілотного дослідження, в неповній сім'ї значно частіше виявляються конфліктні взаємостосунки між матір'ю і дітьми. Зокрема, за отриманими даними, 29,8\% опитаних матерів із повної сім’ї відповіли, що у них практично відсутні конфлікти з дітьми, в той час як у неповній сім'ї на це вказали лише 9,8\% опитаних жінок.

Ще одна складність неповних сімей полягає в тому, що мати після розірвання шлюбу нерідко повертається жити (c) Kompliienko Iryna

DOI (article): https://doi.org/10.32626/2227-6246.2020-49.177-201 
разом із дітьми до своїх батьків. Слід урахувати й те, що іноді моральна і матеріальна підтримка матір'ю своїх батьків сприяє ситуації розлучення, тим більше, що бабуся часто відчуває негативні почуття щодо чоловіка дочки, особливо у разі його спроб займати незалежну і домінуючу позицію в сім'ї. Характерним феноменом взаємостосунків у такій неповній сім’ї буде інверсія виховних ролей, коли роль матері бере на себе бабуся з авторитарними рисами особистості, а роль батька виконує мати або дідусь із твердими рисами характеру і підвищеною принциповістю. У найбільшою мірою травматичній сімейній ситуації виявляються, як правило, хлопчики, позбавлені як материнської любові, так і батьківського авторитету. Матері, зазвичай, можуть перешкоджати зустрічам батька із сином і виявляють до хлопчиків неабияку суворість, яку можна розцінювати як певну реакцію на неприйняття в них небажаних рис колишнього чоловіка. Тому відносно хлопчиків матері часто застосовують погрози, осуд і фізичні покарання. До дівчаток матері ставляться дбайливіше. Проте діти, які залишилися з матір'ю, стають ніби мішенню для зменшення у неї нервової напруги і почуття емоційної незадоволеності. Й усе це відбувається під суворим контролем бабусі та дідуся, що, своєю чергою, суттєво посилює тиск на дітей. Закономірним наслідком відсутності емоційного визнання і розуміння з боку матері є, як правило, наростання психічної напруги у дітей і поява у них невротичних і поведінкових розладів (до останніх ми також відносимо і вживання старшокласниками психоактивних речовин).

Після розлучення колишнє подружжя, швидше за все, не може жити разом, але вони тією чи іншою мірою присутні в житті один одного. I кожному з них відводиться відповідне місце. Неповна сім'я розвивається продуктивно за умови, якщо кожен її член є важливим і потрібним (як своїм дітям, так і щодо соціуму). Багато людей намагаються жити таким чином, ніби інші люди, з якими вони були раніше (C) Kompliienko Iryna DOI (article): https://doi.org/10.32626/2227-6246.2020-49.177-201 
DOI: https://doi.org/10.32626/2227-6246.2020-49 2020. випУск 49

пов'язані, не існують. Водночас усі ці люди певною мірою впливають на життя сім’ї. Проблеми виникають, насамперед, тоді, коли члени родини не знаходять часу, щоб поговорити, сваряться або вважають один одного ворогами. Тому в психологічному плані створюються досить важкі умови для життя дитини, адже кожен дорослий вимагає від неї чогось свого, відмінного від вимог інших, особливо якщо дорослі не розуміють складності такого становища дитини. Іншою проблемною ситуацією є така, коли батьки й діти не спілкуються один з одним. Якщо члени колишнього подружжя не приховують свої стосунки, у дитини, врешті-решт, створюється неабияка можливість вибору стилю власної поведінки, і вона не стає оберегом таємниць дорослих. Подібна проблема часто виникає між розлученими батьками, які, як і раніше, вважають один одного ворогами і використовують дітей як шпигунів. Батьки фактично очікують від дитини різних способів розв'язання своїх проблем, із якими вони не можуть упоратися самі. Звичайно, найімовірнішим є те, що дитина не може розв'язати всі проблеми своїх батьків, і тому часто реагує на таку ситуацію або соматично (своєю хворобою), або поведінковими проявами (непослухом, дивацтвами, вживанням психоактивних речовин тощо). Для дитини корисна ситуація, коли оточуючі їі дорослі $є$ щирими і цілковито відповідають за те, що вони думають i відчувають. Бути відкритим іншій особі зовсім не означає неодмінно любити цю людину. Від колишнього подружжя не можна очікувати, що вони, як і раніше, кохатимуть один одного, але вони не мають нав'язувати дитині певного рішення своїх проблем. Найважливіше питання, яке, врештірешт, виникає в неповній сім’і, - це питання розуміння звільнення своєї дитини від тягаря проблем дорослих.Кожна людина, маючи певні характеристики своєї індивідуальності, привносить із собою в сім'ю неповторне розмаїття почуттів і думок, інтересів і знань, дій і вчинків. I вся ця (C) Kompliienko Iryna

DOI (article): https://doi.org/10.32626/2227-6246.2020-49.177-201 
жива, різноманітна та досить-таки багата сторона життя в сім’і порушується у разі відсутності одного з батьків і не може бути відшкодована ніким або нічим. У дитини, яка живе лише з матір'ю, створюється набагато менше можливостей для ознайомлення з різними варіантами соціального досвіду, істотно звужуються важливі для їі розвитку й особистісного становлення межі міжособистісного спілкування.

Головне, однак, полягає в тому, що недосконалість морально-емоційного світу дитини у неповній сім' відсутності впливу тієї сторони інтимно-емоційної сфери, яка створюється позитивними взаємостосунками подружжя. Цей своєрідний вакуум, яким є в морально-емоційному плані неповна сім'я, не можна компенсувати жодними матеріальними або іншими благами. Цікавим результатом цих проблем i, в першу чергу, складнощів виховної ситуації в неповній сім’ї є нездатність значної кількості матерів опанувати психологічні проблеми, усвідомити свою педагогічну непідготовленість до виховання дитини самостійно, без сторонньої допомоги.

Також слід пам'ятати, що неповна сім'я має досить-таки обмежені виховні можливості, й проблема матерів полягає в тому, що вони не в змозі дати дитині те, що може дати їй повна сім'я. В. Сатир вважає, що всі ці проблеми можна розв'язати. ЖЖінка-матір цілком може мати адекватне настановлення стосовно оточуючих ㄲï чоловіків і бути достатньо зрілою, щоб не створювати у дітей негативного уявлення щодо них. Вона може допомогти своїм дітям установити гарні й близькі стосунки з дорослими чоловіками, яких вона знає і поважає. Такими особистостями можуть бути їі батьки, друзі їі чоловіка або її власні друзі. Перш ніж запропонувати дитині роль помічника в сім'ї, матір повинна пояснити їй, що бути відповідальним за деяку важливу частину сімейного життя зовсім не означає відмовитися від своєї синівської ролі й, виконуючи будь-яку справу, в якій матері вкрай по-

(C) Kompliienko Iryna DOI (article): https://doi.org/10.32626/2227-6246.2020-49.177-201 
трібна допомога, зовсім не означає, що син повинен узяти на себе постійну роль рівноправного помічника (Сатир, 1992).

Отже, взаємостосунки матері та дитини старшого шкільного віку після розлучення батьків характеризуються як дезадаптивні, нерідко - конфліктні, а сам конфлікт характеризується зіткненням протилежно спрямованих цілей, інтересів, позицій, думок суб'єктів міжособистісної взаємодії.

На думку вчених (Tabachnikov, Osukhovskaia, Kioseva, Kharchenko \& Mykhalchuk, 2018: 114-118), однією 3 основних причин дезадаптивних взаємостосунків у родині є стрес, зокрема дитини після розлучення їі батьків, тобто проблемний соціально-психологічний стан дитини у нових умовах сім’і, що розпалася, неадекватність сприйняття членами сім’ї один одного. Найчастіше конфлікт матері та дитини буває спровокований неабиякими протиріччями в ціннісних орієнтаціях самих матерів. Зокрема, діти, як правило, вважають за краще розвиватися в морально-етичній парадигмі своїх батьків. Отже, якщо матері живуть у стані недозволеного внутрішнього когнітивного дисонансу, пов'язаного з наслідками розлучення, діти схильні приймати на себе атрибути однієї зі сторін когнітивного дисонансу матерів і експлікувати відповідну модель поведінки. Зважаючи на те, що взаємостосунки, які складаються між матір'ю і дитиною, великою мірою визначаються внутрішнім станом матері, то змінити їх неможливо без допомоги й особистісного прикладу батька. Демонструючи власний шлях особистісного становлення, батьки, як правило, можуть досить-таки

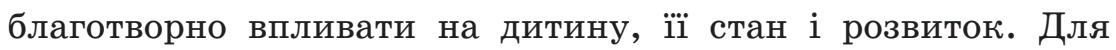
нового рівня міжособистісних взаємостосунків необхідний якісно новий рівень в особистісному розвитку дитини, який, передусім, залежатиме від адаптивних сімейних взаємостосунків.

Отже, негативна варіабельність сімейних цінностей і морально-етичних критеріїв, практична доступність різних ви(C) Kompliienko Iryna

DOI (article): https://doi.org/10.32626/2227-6246.2020-49.177-201 
дів психоактивних речовин (алкоголю, наркотиків, тютюнових виробів) стали реальною причиною активного зростання та розповсюдження споживання психоактивних речовин серед старшокласників і молоді. Безумовно, ця проблема має схожі риси стану залежності від психоактивних речовин у країнах близького та далекого зарубіжжя, тому й особливості моделі адаптивних сімейних взаємостосунків з урахуванням цієї патології повинні мати спільне підгрунтя. Як свідчать епідеміологічні дані, за останні роки захворювання на психічні та поведінкові розлади внаслідок вживання психоактивних речовин в Україні перевищує захворюваність на розлади інших регістрів. Крім того, ситуація в нашій державі характеризується поступовим зростанням показників хімічної (алкогольної, тютюнової, наркотичної тощо) і нехімічної адикцій (Osukhovskaia, 2011: 102-108).

Згідно з даними ВООЗ, алкоголь є найбільш широковживаною психоактивною речовиною серед дітей і підлітків в Україні. Кожен четвертий українець, який страждає на алкогольну залежність, є особою у віці до 35 років (OECD Health Data 2008: How Does Canada Compare (PDF), 2008).

Згідно з проведеним нами пілотним дослідженням (як було зазначено, у цьому дослідженні брали участь 355 старшокласників м. Києва, м. Рівного та м. Миколаєва), серед старшокласників 14-18 років вживають алкоголь близько $87 \%$; палять тютюн - 75\%; мають досвід вживання наркотичних речовин - понад $34 \%$ респондентів. Причиною смертності двох третин молоді у віці від 14 до 20 років є отруєння алкогольними напоями або нещасні випадки внаслідок сп'яніння від психоактивних речовин (Kioseva, 2015: 61-62). За отриманими нами даними, в неповних сім'ях алкогольні напої коли-небудь вживали $24 \%$ десятирічних дітей, 28\% і $31 \%$ одинадцяти- та дванадцятирічних відповідно, $55 \%$ - чотирнадцятирічних, 67\% - п'ятнадцятирічних. Більшість опитаної молоді 15 та 22 років вживають алкоголь

(C) Kompliienko Iryna

DOI (article): https://doi.org/10.32626/2227-6246.2020-49.177-201 
регулярно (83\% і 78\% відповідно). Нами було діагностовано, що вже у семирічному віці досвід вживання алкоголю діти набувають у сім'ях у присутності батьків (тобто, з їхньої ініціативи) в середньому від $15 \%$ до $46 \%$ випадків. Одним із найпоширеніших видів споживання психоактивних речовин є тютюнопаління. За даними статистики, кількість осіб, які щодня викурюють цигарки, становить 10,2 млн осіб, понад 500 тис. нових споживачів приєднується до тютюнопаління щороку (Tabachnikov, Pinchuk, Kharchenko, Osukhovskaia, Tabachnikov, Mazbits, Chepurna, Mykhalchuk, Salden \& Tovalovych, 2018: 229-230). За результатами нашого пілотного дослідження, найпоширеніший вік початку паління серед дітей в Україні - 11-15 років. Тих, хто починає курити раніше 11 років, - близько чверті. За останніми даними, серед старшокласників 14-17 років помітне збільшення курців тютюну з 23,3\% до 44,5\% . Дівчата, переважно, починають курити дещо пізніше хлопців, поступово «наздоганяючи» їх у старших класах і по закінченню середньої школи.

Одним із чинників, який збільшує вживання тютюну, є алкоголь і наркотики. 54\% старшокласників зауважили, що курять тютюн значно більше після вживання алкоголю та наркотиків. Наше дослідження свідчить про те, що 27\% респондентів віком 15-37 років мали досвід вживання будь-яких наркотичних речовин упродовж життя. Значно поширеними серед молоді є каннабіоїди, опіоїди, психостимулятори. Перше вживання наркотичних речовин у $24 \%$ респондентів відбулося у віці 12-16 років, ще у $35 \%$ - від 17 до 18 років, а у віці 19-28 років - у 27\% осіб відповідно. Серед чоловіків 45,6\% вперше спробували наркотичні речовини у віці 12-16 років, а серед жінок $-32,1 \%$ у віці 17-26 років. Наведені дані підтверджують небезпечний період щодо вживання наркотичних психоактивних речовин - підлітковий і старший шкільний вік. Результати нашого дослідження свідчать про те, що $16 \%$ усіх учнів мали (c) Kompliienko Iryna

DOI (article): https://doi.org/10.32626/2227-6246.2020-49.177-201 
досвід вживання, окрім алкоголю або марихуани, психостимуляторів. Найбільший відсоток спостерігався серед учнів професійно-технічних навчальних закладів і закладів вищої освіти I-III рівнів акредитації - по 15-16\% відсотків, дещо менше респондентів - 12-13\% - серед учнів 9-11-х класів закладів середньої освіти. Хлопці вживають наркотичні речовини вдвічі частіше за дівчат.

Рівень споживання психоактивних речовин серед молоді свідчить про низьку ефективність профілактичних заходів щодо вживання цих речовин серед цієї цільової групи. Більшість опитаних починали вживати психоактивні речовини у віці 12-16 років. Однак 25\% респондентів уперше спробували психоактивні речовини в 11 років і раніше. Згідно $з$ нашими дослідженнями, найризикованіший вік - 15 років. Респонденти, які вживають психоактивні речовини (серед молоді 15-20 років), підтвердили, що 17-25\% із них, окрім алкоголю, мають досвід вживання різних видів наркотиків. Серед школярів старших класів лише 23-27\% деколи приймали алкоголь, а регулярно вживають (3-5 і більше разів на місяць) - кожний 4-5-й учень старшого шкільного віку. Споживання психоактивних речовин у цьому віці призводить до суттєвого погіршення здоров'я, а також девіантної поведінки, суїцидальних дій, криміногенності й травматизмy (Balakireva, Bondar \& Pryimak, 2015).

Результати, отримані нами в пілотному дослідженні, підтверджені іншими експериментальними дослідженнями. Дані досліджень «ESPAD Україна», проведених у 2015 р., також свідчать про високий рівень споживання психоактивних речовин серед молоді: в середньому 83,4\% учнів вживали будь-які алкогольні напої хоча б один раз упродовж життя (Tabachnikov, Pinchuk, Kharchenko, Osukhovskaia, Tabachnikov, Mazbits, Chepurna, Mykhalchuk, Salden \& Tovalovych, 2018). У віці 15 років цей показник складає $78,4 \%$, а у $16-17$ - наближається до $85 \%$.

(C) Kompliienko Iryna

DOI (article): https://doi.org/10.32626/2227-6246.2020-49.177-201 


\section{Висновки}

Отже, психологічними чинниками дезадаптивних взаємостосунків одного з батьків і старшокласника в неповній сім’ї ми вважаємо такі, як:

- нездорова, конфліктна обстановка в сім'і;

- ситуація розірвання шлюбу, яка значно загострює саме негативні характеристики подружжя, актуалізує атмосферу взаємної неприязні, ненависті, образ і звинувачень, що не може не позначитися на світовідчутті дитини, її етично-моральних переконаннях, поглядах, настановленнях, ставленні до оточуючих;

- поганий психічний і (або) фізичний стан жінки-матері;

- негативний сімейний досвід матері;

- неіснування (або існування досить незначного) впливу в родині з боку чоловіка (в тому числі - й чоловічого авторитету);

- вживання старшокласниками психоактивних речовин.

Профілактична робота в Україні щодо запобігання вживання психоактивних речовин населенням, безумовно, проводиться, але її масштаби й особливості організації не забезпечують належного ефекту. Досліджувана проблема безпосередньо пов'язана з досягненням адаптивних сімейних взаємостосунків, проте цій проблемі повинна бути приділена особлива увага, що буде зроблено в подальших наших публікаціях.

\section{Література}

Буянов М. И. Ребенок из неблагополучной семьи: записки детского психиатра. Москва : Прогресс, 1988. 136 с.

Гарбузов В. И. Нервные дети: советы врача. Ленинград : Медицина. Ленинградское отделение; Москва : Ассоциативный совет книгоиздателей, 1990. $172 \mathrm{c.}$

Дольто Ф. На стороне подростка / пер. с франц. Е. В. Боевской, О. В. Давтян. Санкт-Петербург : Педагогика, 1997. 234 с.

(c) Kompliienko Iryna

DOI (article): https://doi.org/10.32626/2227-6246.2020-49.177-201 
Киосева Е. В. Инновационное направление в медико-социальной превенции аддиктивных расстройств у студенческой молодежи. $A p$ хів nсuхіатрї. 2015. Т. 21, № 2 (81). С. 61-62.

Лупьян А. Я. Барьеры общения, конфликты, стресс. Минск : Высшая школа, 1986. 202 с.

Максименко С., Ткач Б., Литвинчук Л., Онуфрієва Л. Нейропсихолінгвістичне дослідження політичних гасел із зовнішньої реклами. Психолінгвістика. Психолингвистика. Psycholinguistics. 2019. Вип. 26 (1). С. 246-264. URL : https://psycholing-journal. com/index.php/journal/article/view/715.

Осуховская Е. С. Взаимопотенцирующие процессы, ассоциированные с формированием химических и нехимических аддикций у лиц молодого возраста. Архів психіатрї. 2011. № 4 (67). С. 102-108.

Пожар Л. Психология аномальных детей и подростков. Патопсихология. Москва : Изд-во МГУ; Воронеж, 1996. 128 с.

Раттер М. Помощь трудным детям. Москва : Наука, 1978. 193 с.

Сатир В. Как строить себя и свою семью. Москва : Педагогика Пресс, 1992. 192 c.

Стегачёва С. В. Типы дезадаптивного поведения супружеских пар и их психологическая коррекция: дис. ... канд. психол. наук: 19.00.07. Тамбов, 2004. 145 с.

Табачников С. И., Харченко Е. Н., Приб Г. А., Марценковская И. И., Синицкая Т. В., Власова К. А., Войтенко Ю. В. Медико-социологические аспекты характеристики токсикоманий у лиц подросткового и молодого возраста. Архів псuхіатрї. 2011. Т. 17, № 3 (66). С. 61-66.

Эриксон Э. Детство и общество / пер. с англ. и научная редакция А. А. Алексеева. Санкт-Петербург : Летний сад, 2000. 165 с.

Эриксон Э. Идентичность: юность и кризис / пер. с англ., общая редакция и предисловие А. В. Толстых. Москва : Прогресс, 1996. 124 с.

Balakireva, O. M., Bondar, T. V., \& Pryimak, Yu. Yu. (2015). Smoking, usage of alcohol and drugs among adolescents who are in the process of education: Distribution and Trends in Ukraine: According to the results of the research in 2015 in the paradigm of the international project «European Student Survey on the Use of Alcohol and Other Drugs - ESPAD». Kyiv : Polygraphic Center «Folio». 200 p.

OECD Health Data 2008: How Does Canada Compare (PDF) (2008). Organization for Economic Co-operation and Development. Retrieved 200901-09. URL : http://moz.gov.ua/docfiles/Metodyhni_rekomendacii_ PMD_u_mistah.pdf.

Tabachnikov, $\overline{\text { S. }}$, Osukhovskaia, E., Kioseva, E., Kharchenko, Ye., \& Mykhalchuk, N. (2018). Psychoprevention system for educational psy-

(c) Kompliienko Iryna

DOI (article): https://doi.org/10.32626/2227-6246.2020-49.177-201 
DOI: https://doi.org/10.32626/2227-6246.2020-49

choactivities substance use young persons. Науково-інфорлаційний вісник Академї вищой освіти Украӥни, 2-3 (104-105), 113-124.

Tabachnikov, S. I., Pinchuk, I. Ya., Kharchenko, Ye. M., Osukhovskaia, O. S., Tabachnikov, O. Yu., Mazbits, V. B., et al. (2018). Psychological, clinical and instrumental-laboratory methods for the diagnosis of the usage of psychoactive substances by somatic patients in the practice of family medicine. Apxis ncuxiampii, 24, 4 (95), 229-234.

\section{References}

Buianov, M. I. (1988). Rebenok iz neblagopoluchnoi semi: zapiski detskogo psikhiatra [A child from a dysfunctional family: notes of a child psychiatrist]. Moskva : Progress [in Russian].

Garbuzov, V. I. (1990). Nervnyie deti: sovety vracha [Nervous children: doctor's advice]. Leningrad : Meditsina. Leningradskoie otdeleniie; Moskva : Assotsiativnyi sovet knigoizdatelei [in Russian].

Dolto, F. (1997). Na storone podrostka [On the side of a teenager]. E. V. Boievskaia, O. V. Davtian (Trans.). Sankt-Peterburg : Pedagogika [in Russian].

Lupian, A. Ya. (1986). Bariery obshcheniia, konflikty, stress [Communication Barriers, Conflicts, Stress]. Minsk : Vysshaia shkola [in Russian].

Kioseva, E. V. (2015). Innovatsionnoie napravleniie v mediko-sotsialnoi preventsii addiktivnykh rasstroistv u studencheskoi molodezhi [The innovative direction in the paradigm of medico-social prevention of addictive disorders of students]. Arkhiv psykhiatrii - Archives of psychiatry, 21, 2 (81), 61-62 [in Russian].

Maksymenko, S., Tkach, B., Lytvynchuk, L., \& Onufriieva, L. (2019). Neiropsykholinhvistychne doslidzhennia politychnykh hasel iz zovnishnoi reklamy [A neuropsycholinguistic research of political slogans from outdoor advertising]. Psykholinhvistyka. Psikholingvistika. Psycholinguistics - Psycholinguistics. Psycholinguistics. Psycholinguistics, 26 (1), 246-264. Retrieved from https://psycholing-journal. com/index.php/journal/article/view/715 [in Ukrainian].

Osukhovskaia, E. S. (2011). Vzaimopotentsiruiushchiie protsessy, assotsiirovannyie $\mathrm{s}$ formirovaniiem khimicheskikh i nekhimicheskikh addiktsii u lits molodogo vozrasta [Inter potentiate processes associated with the formation of chemical and non-chemical addictions among young people]. Arkhiv psykhiatrii - Archives of psychiatry, 4 (67), 102-108 [in Russian].

(C) Kompliienko Iryna

DOI (article): https://doi.org/10.32626/2227-6246.2020-49.177-201 
Pozhar, L. (1996). Psikhologiia anomalnykh detei i podrostkov. Patopsikhologiia [Psychology of abnormal children and adolescents. Pathopsychology]. Moskva : Izdatelstvo MGU; Voronezh [in Russian].

Ratter, M. (1978). Pomoshch trudnym detiam [Help for difficult children]. Moskva : Nauka [in Russian].

Satir, V. (1992). Kak stroit sebia i svoiu semiu [How to build yourself and your family]. Moskva : Pedagogika Press [in Russian].

Stegacheva, S. V. (2004). Tipy dezadaptivnogo povedeniia supruzheskikh par i ikh psikhologicheskaia korrektsiia [Types of maladaptive behavior of married couples and their psychological correction]. Candidate's thesis. Tambov [in Russian].

Tabachnikov, S. I., Kharchenko, Ye. M., Prib, G. A., Martsenkovskaia, I. I., Sinitskaia, T. V., Vlasova, K. A., et al. (2011). Mediko-sotsiologicheskiie aspekty kharakteristiki toksikomanii u lits podrostkovoho i molodogo vozrasta [Medical and social aspects of description of toxicomaniia for teenagers and young adults]. Arkhiv psykhiatrii Archives of psychiatry, 17, 3 (66), 61-66 [in Russian].

Erickson, E. (2000). Detstvo $i$ obshchestvo [Childhood and society]. A. A. Alekseev (Trans.). Sankt-Peterburg : Letnii Sad [in Russian].

Erickson, E. (1996). Identichnost: yunost $i$ krizis [Identity: Youth and Crisis]. A. V. Tolstykh (Trans.). Moskva : Progress [in Russian].

Balakireva, O. M., Bondar, T. V., \& Pryimak, Yu. Yu. (2015). Smoking, usage of alcohol and drugs among adolescents who are in the process of education: Distribution and Trends in Ukraine: According to the results of the research in 2015 in the paradigm of the international project «European Student Survey on the Use of Alcohol and Other Drugs - ESPAD». Kyiv : Polygraphic Center «Folio».

OECD Health Data 2008: How Does Canada Compare (PDF) (2008). Organization for Economic Co-operation and Development. Retrieved 2009-01-09. Retrieved from http://moz.gov.ua/docfiles/Metodyhni_ rekomendacii_PMD_u_mistah.pdf.

Tabachnikov, S., Osukhovskaia, E., Kioseva, E., Kharchenko, Ye., \& Mykhalchuk, N. (2018). Psychoprevention system for educational psychoactivities substance use young persons. Naukovo-informatsiinyi visnyk Akademii vyshchoi osvity Ukrainy - Scientific-informational bulletin of the Academy of Higher Education of Ukraine, 2-3 (104-105), 113-124.

Tabachnikov, S. I., Pinchuk, I. Ya., Kharchenko, Ye. M., Osukhovskaia, O. S., Tabachnikov, O. Yu., Mazbits, V. B., et al. (2018). Psychological, clinical and instrumental-laboratory methods for the diagnosis of the usage of psychoactive substances by somatic patients

(C) Kompliienko Iryna

DOI (article): https://doi.org/10.32626/2227-6246.2020-49.177-201 
DOI: https://doi.org/10.32626/2227-6246.2020-49 2020. ВиПУСК 49

in the practice of family medicine. Arkhiv psykhiatrii - Archive of psychiatry, 24, 4 (95), 229-234.

\section{Комплієнко Ірина. Неповна сім'я як чинник вживання старшокласника- ми психоактивних речовин}

\section{АНОТАЦІЯ}

Mета cmammi - окреслити негативний вплив розпаду сім'ї на взаємостосунки батьків і дітей; описати психологічні типи взаємостосунків батьків і дітей; виокремити психологічні чинники дезадаптивних взаємостосунків одного з батьків і старшокласника в неповній сім'ї.

Для розв'язання поставлених у роботі завдань використано такі теоретичні методи дослідження: категоріальний, структурно-функціональний, аналіз, систематизація, моделювання, узагальнення. У якості емпіричних методів обрано методи анкетування й інтерв'ювання.

Результати дослідження. Зазначено, що нерідко наслідком розпаду сім'ї є зміна ставлення дитини до своєї матері. Іноді у неї виникає досить-таки загострене почуття жалості й ніжності до неї; в інших випадках дитина звинувачує матір у розірванні стосунків із батьком, тим більще, якщо в ньому дитина бачить і цінує такі якості та властивості характеру, які не помічає мати. Або, навпаки, дитина може не помічати ті сторони батьківського характеру, які стали джерелом розчарування для ії матері. Унаслідок цього дитина починає досить-таки критично ставитися до матері й, таким чином, за своєю суттю ніби "втрачає» для себе і другого з батьків. Збільшення відстані між дитиною та батьками має місце й тоді, коли мати, пригнічена своїм горем і новими додатковими турботами, не знаходить достатньо часу для занять із дитиною. Нерідко буває й так, що дитина в таких випадках розглядається покинутою мамою як зайвий тягар, що суттєво ускладнює ії подальші життєві перспективи. У результаті цього виникає доволі грубе, часом зовсім несправедливе ставлення матері до дитини, що, своєю чергою, вкрай згубно позначається на ії моральному розвитку, втім, як і несамовита материнська любов або любов-жертва, що нерідко виникає в такій ситуації і не знає розумних меж.

Доведено, що у новоствореній сім'ї також нерідко виникають неабиякі труднощі адаптації дітей до нових умов життєдіяльності. Дитина в старшому шкільному віці вирізняється психікою, яка ще не цілковито (C) Kompliienko Iryna

DOI (article): https://doi.org/10.32626/2227-6246.2020-49.177-201 
DOI: https://doi.org/10.32626/2227-6246.2020-49 2020. випуск 49

срормована, якій легко завдати шкоду. Дитині, як правило, нелегко звикнути до вітчима або мачухи, і сам прочес психологічної адаптації часом набуває тривалого і болісного характеру. Досить часто підозріле, насторожене, а іноді - й узагалі вороже ставлення до нового батька чи матері зникає упродовж тривалого періоду часу, навіть якщо один із батьків виявляє максимальну увагу до дитини. У багатьох же випадках сімейні взаємостосунки залишаються деструктивними.

Висновок. Психологічними чинниками дезадаптивних взаємостосунків одного з батьків і старшокласника в неповній сім'ї ми вважаємо такі, як: нездорова, конфрліктна обстановка в сім'ї; ситуація розірвання шлюбу, яка значно загострює саме негативні характеристики подружжя, актуалізує атмосферу взаємної неприязні, ненависті, образ і взаємних звинувачень, що не може не позначитися на світовідчутті дитини, іï етично-моральних переконаннях, поглядах, настановленнях, ставленні до оточуючих; поганий психічний і (або) фізичний стан жінки-матері; негативний сімейний досвід матері; неіснування (або існування досить незначного) впливу в родині з боку чоловіка (в тому числі - й чоловічого авторитету); вживання старшокласниками психоактивних речовин.

Ключові слова: неповна сім'я, повна сім'я, психоактивні речовини, дезадаптивні взаємостосунки, конфлліктна обстановка, ситуація розірвання шлюбу, негативний сімейний досвід.

Комплиенко Ирина. Неполная семья как фактор употребления старшеклассниками психоактивных веществ

\section{АННОТАЦИЯ}

Цель данной статьи - определить, насколько негативно распад семьи влияет на взаимоотношения родителей и детей; описать психологические типы взаимоотношения родителей и детей; выделить факторы дезадаптивных взаимоотношений родителя и старшеклассника в неполной семье.

Для решения поставленных в работе задач использованы следующие теоретические методы исследования: категориальный, структурно-фрункциональный, анализ, систематизация, моделирование, обобщение. В качестве эмпирических методов использованы методы анкетирования и интервьюирования.

(C) Kompliienko Iryna

DOI (article): https://doi.org/10.32626/2227-6246.2020-49.177-201 
Результаты исследования. Отмечено, что нередко следствием распада семьи является изменение отношения ребенка к своей матери. Иногда у него возникает довольно-таки обостренное чувство жалости и нежности к ней; в других случаях ребенок обвиняет мать в уходе отиа, тем более, если в нем ребенок видит и ценит такие качества и свойства характера, которые не замечает мать. Или, наоборот, ребенок может не замечать те стороны характера отиа, которые стали источником разочарования для его матери. В результате ребенок начинает довольно-таки критически относиться к матери и, таким образом, по своей сути как бы «теряет» для себя и другого родителя. Увеличение расстояния между ребенком и родителями имеет место и тогда, когда мать, подавленная своим горем и новыми дополнительными заботами, не находит достаточно времени для занятий с ребенком. Нередко бывает и так, что ребенок в таких случаях рассматривается брошенной мамой как лишний груз, существенно затрудняющий ее дальнейшие жизненные перспективы. В результате этого возникает достаточно грубое, порой - совсем несправедливое отношение матери к ребенку, что, в свою очередь, крайне пагубно сказывается на его нравственном развитии, впрочем, как и неистовая материнская любовь или любовь-жертва, нередко возникающая в такой ситуации и не знающая разумных пределов.

Доказано, что во вновь созданной семье также нередко возникают серьезные трудности адаптации детей к новым условиям жизнедеятельности. Ребенок в старшем школьном возрасте отличается еще не совсем сложившейся психикой, которой очень легко нанести вред. Ребенку, как правило, нелегко привыкнуть к отчиму или мачехе, и сам этот прочесс психологической адаптации принимает длительный и болезненный характер. Достаточно часто подозрительное, настороженное, а иногда - и вообще враждебное отношение к новому отиу или матери исчезает в течение длительного периода времени, даже если один из родителей проявляет максимальное внимание к ребенку. Во многих же случаях семейные взаимоотношения остаются деструктивными.

Вывод. Психологическими факторами дезадаптивных взаимоотношений родителя и старшеклассника в неполной семье мы считаем такие, как: нездоровая, конфликтная обстановка в семье; ситуация расторжения брака, значительно обостряющая именно негативные характеристики супругов, актуализирующая атмосреру взаимной неприязни, ненависти, обид и обвинений, что не может не сказаться на ми(C) Kompliienko Iryna

DOI (article): https://doi.org/10.32626/2227-6246.2020-49.177-201 
DOI: https://doi.org/10.32626/2227-6246.2020-49 2020. ВИПУСК 49

роощущении ребенка, его нравственно-моральных убеждениях, взглядах, установках, отношении к окружающим; плохое психическое и (или) физическое состояние женщины-матери; отрицательный семейный опыт матери; недостаточное (или незначительное) влияние на семью мужа (в том числе - и мужского авторитета); употребление старшеклассниками психоактивных веществ.

Ключевые слова: неполная семья, полная семья, психоактивные вещества, дезадаптивные взаимоотношения, конфликтная обстановка, ситуация расторжения брака, отрицательный семейный опыт.

Original manuscript received April 10, 2020 Revised manuscript accepted May 26, 2020 